\title{
ABSTRACTS
}

\section{South Africa's System of Official Languages}

\author{
By Klavs Skovsholm
}

From the moment the foundations of today's Republic of South Africa were laid down in her first Constitution of 1909 until the entry into force of her Interim Constitution in 1994, South Africa has had two official languages: English and Afrikaans. Throughout this period of time, these two languages were treated on a footing of equality - with the exclusion of all local languages spoken by the vast majority of black South Africans. With the exception of the Constitutional clause on voting rights, the language clause was the only Constitutional clause which could not be changed by the South African Parliament by simple majority.

The Interim Constitution broke radically with this rule by introducing 11 official languages. A rule which is upheld in the South Africa's Final Constitution of 1996.

This article places its emphasis on the current rules of official languages under the Final Constitution. It is argued that these rules are not as onerous as they may seem at a first reading, and, in spite of the clear goal of a multilinguistic society, in reality some languages are used more frequently than others. In addition to looking at the Constitutional provisions, this article gives some examples as to how the South African Society has responded to having 11 official languages in the Final Constitution.

\section{Demilitarisation and Democratic Re-orientation in Nigeria: Issues, Problems and Prospects}

\section{By Said Adejumobi}

In the last decade and a half (1984-1999), Nigeria existed under brutal military dictatorship, a situation which facilitated the militarisation of politics, the economy and the civil society. Although a military disengagement process was recently completed in the country in May 1999, in which elected political leaders took over the reigns of power, however, the process of demilitarisation and the establishment of a stable and enduring democratic order is yet to be accomplished. The nascent democratic institutions and processes remain very fragile and susceptible to a military backlash. The task of genuine demilitarisation in Nigeria, the paper 
argues, will involve the deconstruction of the institutional base and norms of militarism at the levels of state management, the economy and civil society. Such will include practical policy steps in three major areas. These include, addressing what the author refers to as the military question, the reclaiming of public institutions and the democratisation of the civil society. These elements the paper submits, would constitute the building blocks of a new and enduring democratic order in Nigeria.

\section{Integrated Nigerian Immigrants in Douala - Problems and Insertation Strategies}

\section{By Blaise-Jacques Nkene}

This paper is based on a field-research between July and September 1999 in DoualaCameroon. In this coastal town, situated in the central belt of Africa and characterised by both cosmopolitanism and distrust towards foreigners, exists an important colony of Nigerians, which by the years have succeeded to become deeply rooted to an extent that contrasts radically with the precarious situation of other foreigners. The present study intends to reveal the rules and stakes of the game of integrating foreigners into an urban environment focusing on the strategies as well as the mechanisms of adaptation used by the Nigerian immigrants. The author demonstrates how, even facing an urban environment whatsoever repulsive it may be, the immigrants have been successful to become an indispensable factor for the cohesion of both social and economic life. 